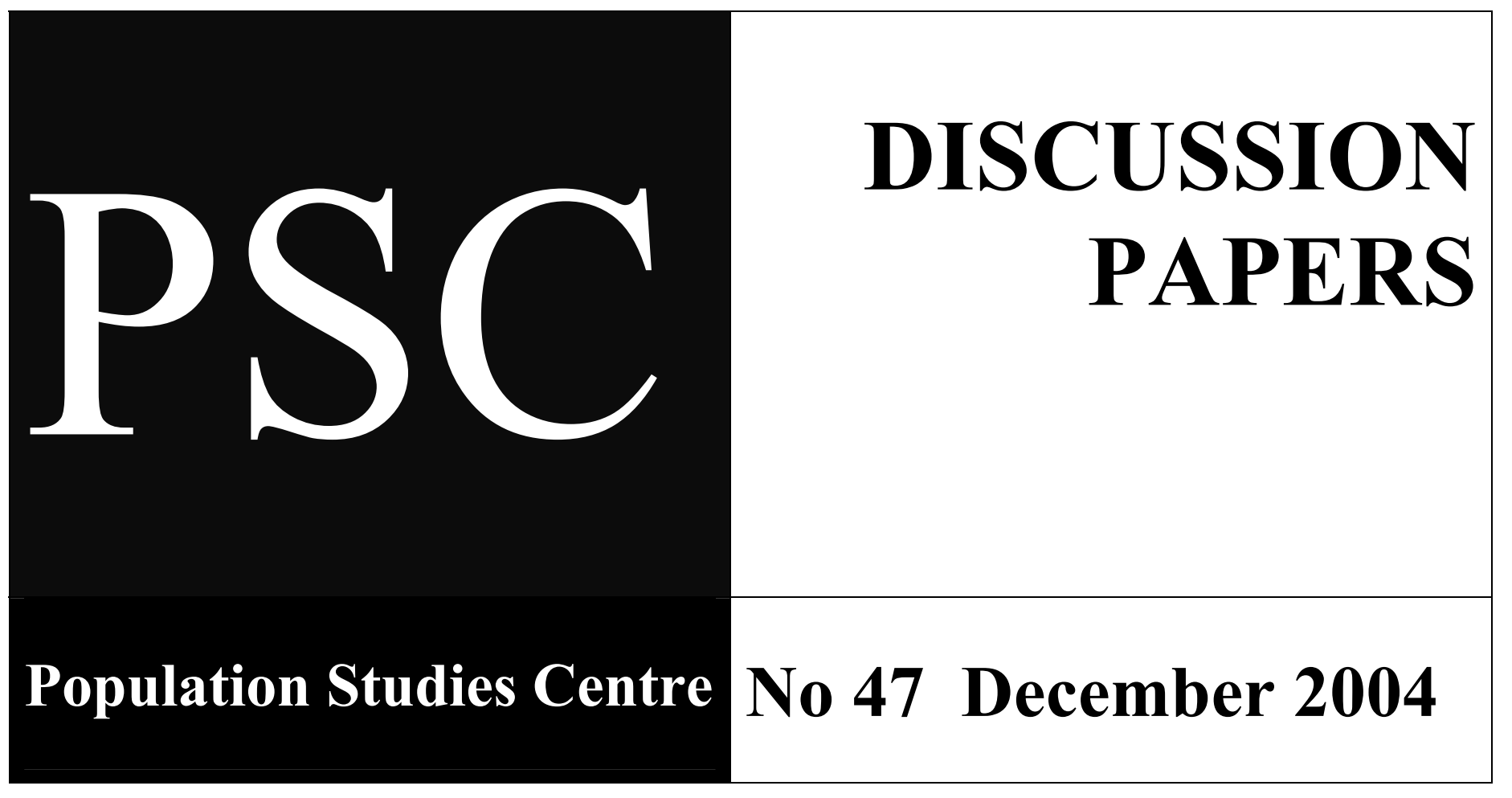

\title{
A Meta-Analytic Assessment of the Effect of Immigration on Wages
}

\author{
Simonetta Longhi \\ Peter Nijkamp \\ Jacques Poot
}

University of Waikato

Te Whare Wānanga $\overline{0}$ Waikato

HAMILTON NEW ZEALAND 
The Population Studies Centre was established at the University of Waikato in 1982.

POPULATIONS STUDIES CENTRE DISCUSSION PAPERS are intended as a forum for the publication of selected papers on research within the Centre, for the discussion and comment within the research community and among policy analysts prior to more formal refereeing and publication.

Discussion Papers can be obtained in pdf form from the centre's website at http://www.waikato.ac.nz/wfass/populationstudiescentre

The views expressed in this discussion paper are those of the authors and do not reflect any official position on the part of the Centre.

(C) Population Studies Centre

University of Waikato

Private Bag 3105

Hamilton

New Zealand

www.waikato.ac.nz/wfass/populationstudiescentre

pscadmin@,waikato.ac.nz

ISBN: 1-877149-48-9 


\title{
A Meta-Analytic Assessment of the Effect of Immigration on Wages*
}

\author{
Simonetta Longhi \\ Free University, Amsterdam, The Netherlands \\ Peter Nijkamp \\ Free University, Amsterdam, The Netherlands \\ Jacques Poot \\ University of Waikato, Hamilton, New Zealand
}

\begin{abstract}
In our increasingly interconnected and open world, international migration is becoming an important socio-economic phenomenon for many countries. Since the early 1980s, many studies have been undertaken of the impact of immigration on host labour markets. Borjas (2003) noted that the estimated effect of immigration on the wage of native workers varies widely from study to study and sometimes even within the same study. In addition, these effects cluster around zero. Such a small effect is a rather surprising outcome, given that in a closed competitive labour market an increase in labour supply may be expected to exert a downward pressure on wages.

We revisit this issue by applying meta-analytic techniques to a sample of eighteen papers, which altogether generated 348 estimates of the percentage change in the wage of a native worker with respect to a one percentage point increase in the ratio of immigrants over native workers. While many studies in our sample employ US data, estimates are also obtained from Germany, The Netherlands, France, Norway, Austria, Israel and Australia. Our analysis shows that results vary across countries and are inter alia related to the type of modelling approach. Technical issues such as publication bias and quality of the estimates are addressed as well. A negative but small effect of immigration on wages of native groups with similar skills appears rather robust.
\end{abstract}

JEL classification: C51, F22, J31, J61

Keywords: Immigration; Labour market; Factor substitution; Meta-analysis

ISBN: $1-877149-48-9$

\footnotetext{
* Part of the research on this paper was carried out while Simonetta Longhi was a visitor in the School of Economics and Finance of Victoria University of Wellington, New Zealand. Financial support from the School is gratefully acknowledged. We are grateful for comments from Tom Stanley and Raymond Florax on an earlier version of this paper. Corresponding author: Jacques Poot, Population Studies Centre, University of Waikato, Private Bag 3105, Hamilton, New Zealand. E-mail: jpoot@waikato.ac.nz
} 


\section{Introduction}

While waves of migration have occurred since the dawn of human existence, the crossborder movement of people has only become a truly global phenomenon in recent decades. The major driving forces are those of economic globalisation, regional economic integration, and increasing political instability around the world. We estimate - based on recent trends - that at present more than 160 million people, including about 20 million refugees, are long-term residents of countries other than their own. This number has more than doubled since the 1960s (IOM, 2000).

However, the scope for further increases is huge. Migrants account at present for only about 2.5 percent of the world population, although the 'migrant density' varies markedly across countries and exceeds ten percent in a number of developed countries. Large and persistent differences in living standards across countries, political turmoil and labour market tensions that arise from ageing labour forces in developed economies versus youthful ones in less developed countries, all constitute push and pull factors which create a potential for acceleration in international movement, but also strong political pressures to strengthen barriers to inward flows. ${ }^{1}$ The perceived promise to some, and perceived threat to others, of further migration flows has led to considerable research on the economic, social and environmental impact of immigration, particularly among highly developed economies (surveyed in, e.g., Castles and Miller, 1993; Stalker, 1994; Gorter et al., 1999; Djaije, 2001).

Economic aspects of migration, such as the determinants of flows, the adaptation or assimilation of migrants and the consequences for labour markets have been particularly well researched (see, e.g., the collection of 102 papers in Zimmermann and Bauer, 2002; and the survey by Borjas, 1999). This literature concludes that, by and large, immigration has not been detrimental to the host economy and that in many cases it may have contributed to economic growth. However, for policy analysis and a better understanding of the impact of immigration on labour markets and the economy, it is useful to complement such broad qualitative conclusions with a more precise quantitative research synthesis. Such is the purpose of the present paper with respect to one core issue: the impact of immigration on wages.

Borjas (2003, p.1335) recently noted that "the measured impact of immigration on the wage of native workers fluctuates widely from study to study (and sometimes even within the same study) but seems to cluster around zero". This observation is rather puzzling from the perspective of standard economic analysis, as an increase in labour supply may be expected to put downward pressure on wages in a competitive labour market.

In the empirical literature there is a general consensus that the effect of immigration on natives' wages is statistically significant, but much smaller that what is expected. Several suggestions have been put forward in the literature to explain the absence of a

\footnotetext{
${ }^{1}$ The Economist (2002) provides a broad overview of the issues.
} 
noticeable effect of immigration on wages. These arguments can be grouped under three headings: (i) openness of the labour market, (ii) difficulties in designing the right empirical test of the hypothesis, and (iii) institutional and other factors that impede competitive forces. For example, one can argue under (i) that an immigration shock raises the return to capital, which in an open economy attracts an inflow of capital until capital returns have again been spatially equalised. Alternatively, natives may move out of areas of immigrant settlement. Both forces offset initial declines in wages. In the end, as long as there are constant returns to scale, the competitive open economy may be merely larger when prices and wages have returned to 'normal'.

There are many assumptions underlying the above argument. To obtain insight into possible links between the theory, the design of empirical research and the conclusions drawn, we adopt a meta-analytic approach. Meta-analysis is a quantitative form of research synthesis that aims to extract useful generalisations from a large body of diverse literature. Meta-analysis has become well established in the experimental sciences (see, for example, Cooper and Hedges' 1994 handbook), but has also recently been growing in popularity in economics, particularly in environmental economics (e.g. van den Bergh et al., 1997, and Florax, 2002a), but also in labour economics. ${ }^{2}$ The total number of published applications of meta-analysis in economics now exceeds one hundred. Stanley (2001) provides an introductory overview and concludes that this form of research synthesis can enhance conventional narrative literature surveys considerably.

While the labour market impact of immigration can have many dimensions, such as the effects of immigration on natives' employment, unemployment, labour force participation, hours worked, structure of the market and institutions, most of the empirical research has been concerned with wages. The largest dataset that could be compiled for meta-analysis informs on the effect of immigration on wages. This is therefore the primary focus of the present paper. Other labour market impacts will be addressed in a future paper. In addition to adopting a meta-analytic approach, another difference with the earlier literature on the wage impact of immigration is that the present paper uses estimates for a range of countries, while major narrative surveys of the literature such as Borjas (1999) are almost exclusively concerned with evidence for the United States.

The next section briefly reviews some of the theoretical issues that have underpinned the specification of empirical research on the wage impact of immigration. This is followed by a discussion of the sample of studies to which meta-analytical methods are applied in Section 3. Descriptive statistics are provided and discussed as well. Taking into account the multivariate nature of the research design, a meta-regression

\footnotetext{
${ }^{2}$ Examples in labour economics include Card and Krueger (1995) and Neumark and Wascher (1998) on minimum wage effects, Jarrel and Stanley (1990) on the union-nonunion wage gap, Doucouliagos (1995) on the effects of union participation on productivity, Doucouliagos (1997) on the aggregate demand for labour, Stanley and Jarrel (1998) on the gender wage gap, Ashenfelter et al. (1999) on the rate of return to education, and Nijkamp and Poot (forthcoming) on the wage curve.
} 
analysis is conducted in Section 4. Various sensitivity analyses are also conducted in that section. Section 5 sums up and provides suggestions for further work in this area.

\section{Theoretical Considerations}

As already noted, a common fear expressed by many people who oppose immigration is that immigration shocks exert a downward pressure on the wage of those who are potential substitutes for immigrants in the labour market. However, surveys of the empirical literature suggest that the negative effect of immigration on wages of natives is rather small, often negligible and sometimes even of the opposite sign (e.g. Friedberg and Hunt, 1995; Borjas, 1999). These findings appear to contradict standard neoclassical theory in which a positive supply shock in a closed labour market may be expected to lower the price of labour. Three sets of explanations can be put forward: either the conducted econometric analyses have been inappropriate, or there are market forces at work that offset the potential downward effect on wages, or institutional factors stop markets from adjusting as expected following an immigration shock. The first two explanations have been investigated in the literature (e.g. Borjas, 2003), but the third one appears at present still under-researched. We will address this issue in the context of differences in findings between US and European results.

The key problem is the non-experimental nature of the two common empirical approaches in the literature. They are the 'area' approach and the 'factor proportions' approach. The area approach exploits the fact that immigration is spatially highly concentrated, so that a negative spatial correlation may be expected between the proportion of the labour force in local labour markets that are immigrants and the wages of natives who they can substitute for. The specification of the regression equation in the area approach is rarely built up from theoretical microfoundations.

In contrast, the factor proportions approach has a much stronger theoretical basis in that it analyses the wage effect of immigration by considering native and immigrant workers as separate production inputs and by simulating the effect of a supply shock given a specific production technology. Thus, after assuming a certain elasticity of substitution between skilled and unskilled workers - usually derived from other studies - and under the assumption that immigrants have significantly lower skills than natives, the elasticities of substitution between native and immigrant workers are estimated. Besides the higher number of assumptions needed for the estimation of the effect of immigration on wages, the factor proportions approach may also suffer from the omission of certain consequential influences on local labour markets such as changes in the composition of demand and induced capital inflows.

While wage effects estimated by both approaches are included in the meta-analysis, the issue of model misspecification is best illustrated by means of the area approach.

The generic regression model to test the impact of immigration on local labour market outcomes is (Borjas, 1999, p. 1735): 


$$
\Delta y_{j s}\left(t, t^{\prime}\right)=\beta \Delta m_{j s}\left(t, t^{\prime}\right)+\mathbf{x}_{\mathrm{js}}{ }^{\prime} \boldsymbol{\alpha}+u_{j s}\left(t, t^{\prime}\right)
$$

in which $\Delta y_{j s}\left(t, t^{\prime}\right)$ is the change between years $t$ and $t^{\prime}$ in the measure of the labour market outcome experienced by natives who live in region $j$ and belong to skill group $s, \Delta m_{j s}\left(t, t^{\prime}\right)$ is the change in the stock of immigrants relative to the stock of natives in that region for that skill group over that period, $\mathbf{x}_{\mathrm{js}}$ is a vector of control variables with coefficient vector $\alpha$ and $u_{j s}$ is the stochastic error. In this paper we limit the analysis to the impact of immigration on the wages of natives and earlier immigrants. The parameter of interest is $\beta$. Estimates of $\beta$ vary across studies and even within studies across specifications. Such a variability, which is probably not only due to sampling variation, might have three potential explanations. Either the equations are misspecified due to omitted variable bias, or the migration shock itself is endogenous, or the 'true' effect depends on the specific situation that has been analysed (country, period, type of data). The case of a varying parameter $\beta$ is referred to as the case of heterogeneity in meta-analysis.

With respect to the issue of misspecification, Borjas (1999) notes that the wages observed in local labour markets may change over time due to spatial forces that are not well understood and in any case not modelled in the regression equations. With respect to the issue of heterogeneity, there are statistical tests to identify this (see e.g., Shadish and Haddock, 1994). Meta-regression analysis is commonly used to identify specific causes of heterogeneity.

With respect to the endogeneity problem it should be noted that migrants are particularly attracted to regions where wage growth is the highest. The endogeneity of the immigrant stock suggests that OLS leads to inconsistent estimates and that an instrumental variable (IV) approach is essential.

One of the main problems in this literature is to find suitable instruments: variables that explain inward immigration, but are not directly related to changes in natives' wages. As governments do not force migrants to settle in specific locations following some experimental design (and in most countries internal migration is free in any case so that the within-country movement of immigrants could offset an exogenous settlement policy), a common instrument is the migrant stock in the previous period. Because there is a well-established fact that migrants cluster and trot well-worn paths from areas of origin to areas of destination (see e.g., Gorter et al., 1999), this instrument usually has a high correlation with current inflows. Nonetheless, the predetermined migrant stock is not a good instrument when there is spatial persistence in wage growth. ${ }^{3}$

Given the problem of finding correct instruments, there has been a search for truly exogenous immigration shocks in local labour markets such as the 1980 influx of

\footnotetext{
${ }^{3}$ When there is spatial persistence in wage growth, the past migrant stock will be highly correlated with current wage growth and therefore not suitable as an instrument for the current migrant inflow rate.
} 
Cuban immigrants to Miami (the so-called Mariel boat lift) which increased Miami's labour force by seven percent almost overnight. By means of the standard differencein-differences estimator, this 'natural experiment' suggested that the large immigration shock had no impact on Miami's native outcomes (Card, 1990).

The example of the Mariel boatlift suggests that even when very good instruments are available, the wage effect $\beta$ might still not be estimated correctly in (1) and may therefore continue to be small or statistically insignificant due to various processes not being taken into account. These processes include: (i) the growth in local demand due to immigrant expenditures, (ii) the inflow of capital in response to increasing local demand and the increase in the rate of return to capital, (iii) outward migration of natives, (iv) a local re-allocation of resources across sectors and associated adjustment of interregional trade (the Heckscher-Ohlin effect), (v) and real wage growth of natives due to immigration-induced technological change and/or economies of scale (see e.g., Poot et al., 1988).

Given such endogenous processes following an immigration shock, we can conclude that the wage effect will be larger in more closed labour markets, and in the short run (when the offsetting factors have not had sufficient time to influence the local labour market) than in the long run. This suggests that the wage effect is best measured where there is no native adjustment process possible. A clever approach, adopted by Borjas (2003), focuses on the distribution of workers across levels of experience in the US national labour market, which may be considered closed with respect to natives, as US emigration rates are small. Given the concentration of new immigrants in certain (low) skill/experience groups, the effect of wages on these workers can be identified. This research suggests a value for $\beta$ with respect to weekly wages of around -0.6 , which can be converted with the US data into an elasticity of -0.4 , i.e., a ten percent supply shock in a particular skill/experience group lowers the wage in that group by four percent. It is therefore, not surprising that this small wage effect is in practice swamped by the other endogenous processes following an immigration shock outlined above.

There is, however, as yet no agreement on which adjustment process is primarily responsible for the small effect of an immigrant shock on wages. There is, for example, no conclusive evidence that an immigration shock leads to net outward migration of natives. Card and DiNardo (2000) find the opposite effect: the same areas tend to attract both immigrants and natives. However, earlier, Borjas et al. (1997) argue that such observations are spurious due to the spatial variation in the growth paths of regions and that a correct estimation of the effect of an immigration shock on the local growth path then involves double differencing of the data. After carrying out such double differencing, Borjas et al. (1997) find strong evidence of displacement of natives by immigrants. Borjas $(1999$, p. 1752) concludes that "the specification of a clear counterfactual is crucial in measuring and understanding the link between immigration, native migration decisions, and the impact of immigrants on the wage structure". The meta-analysis conducted in the remainder of this paper provides some insight into how data and research design have affected the conclusions drawn on this important issue of the immigration debate. 


\section{The Sample of Studies}

The primary studies summarised in our meta-analysis have been selected via extensive searches in EconLit and Google. The keywords for the search were: [(immigration OR immigrant) AND (wage OR earnings)]. Further references to primary studies were collected by means of so-called snowballing techniques from literature reviews by Friedberg and Hunt (1995) and Borjas (1999), as well as from the empirical studies already collected with the previous method.

The majority of studies analysing the wage effect of immigration estimate regressions by means of equation (1), i.e., in which local wages are explained - among other variables - by the share of immigrants in the local labour market. The so-called effect size we study by means of meta-analysis - and which is going to be the dependent variable in the meta-regression of the next section - is the $\beta$ coefficient of the immigrants' share. Since some primary studies report elasticities rather than the $\beta$ coefficients, we convert such elasticities to $\beta$ coefficients by means of the following simple relationship: ${ }^{4}$

$$
\frac{\partial \log w_{j s}\left(t, t^{\prime}\right)}{\partial \Delta m_{j s}\left(t, t^{\prime}\right)}=\beta=\frac{\partial \log w_{j s}\left(t, t^{\prime}\right)}{\partial \log \Delta m_{j s}\left(t^{\prime}, t\right)} \times \frac{1}{\Delta m_{j s}\left(t, t^{\prime}\right)}
$$

This implies, for example, that if an elasticity is reported of -0.02 and the observed average immigration shock increased the proportion of immigrants in the local labour market from four to nine percent, the effect size is $-0.02 \times 20=-0.4$.

As noted in the previous section, another strand of the literature - the so-called factor proportions approach - analyses the wage effect of immigration by considering native and immigrant workers as separate production inputs and by simulating the effect of a supply shock given a specific production technology. Such studies typically estimate and use elasticities of substitution between native and immigrant workers, and again the resulting elasticities are converted to $\beta$ coefficients as above.

Our final meta-database consists of 348 effect sizes (estimates of $\beta$ ) collected from a sample of eighteen studies analysing the effect of immigration on wages of native and/or previous immigrant workers. Table 1 shows the number of effect sizes obtained from each study and Figure 1 plots the value of such effect sizes in ascending order. As the figure clearly shows - and as already noted by Borjas (2003) - the majority of effect sizes are clustered around zero. The effect sizes are fairly symmetrically distributed although the distribution of the effect sizes appears to be non-normal and also somewhat negatively skewed.

\footnotetext{
${ }^{4}$ The standard errors of each effect size are recovered in way that ensures that the $t$-values are exactly the same before and after the transformation. Hence the transformation does not affect the significance level of the compared effect sizes.
} 
Table 1: Number of effect sizes per study

\begin{tabular}{clc}
\hline $\begin{array}{c}\text { Study's } \\
\text { Identification Number }\end{array}$ & \multicolumn{1}{c}{ Author(s) } & $\begin{array}{c}\text { Number of } \\
\text { Effect Sizes Collected }\end{array}$ \\
\hline 1 & Grossman (1982) & 3 \\
2 & Borjas (1987) & 48 \\
3 & Altonji and Card (1991) & 28 \\
4 & Hunt (1992) & 5 \\
5 & De New and Zimmermann (1994) & 8 \\
6 & Enchautegui (1995) & 16 \\
7 & Borjas et al. (1996) & 20 \\
8 & Winter-Ebmer and Zweimuller (1996) & 8 \\
9 & Greenwood et al. (1997) & 32 \\
10 & Bauer (1998) & 18 \\
11 & Pedace (1998) & 12 \\
12 & Winter-Ebmer and Zimmermann (1998) & 8 \\
13 & Card (2001) & 28 \\
14 & Friedberg (2001) & 15 \\
15 & Addison and Worswick (2002) & 23 \\
16 & Hartog and Zorlu (2002) & 20 \\
17 & Borjas (2003) & 48 \\
18 & Hofer and Huber (2003) & 8 \\
\hline Total & & 348 \\
\hline
\end{tabular}

Figure 1 also suggests that some outliers are present in our data set. In order to avoid a major influence of outliers on the results, three effect sizes that are greater than six in absolute value are omitted from the analysis (one each from Enchautegui, 1995; Friedberg, 2001; and Addison and Worswick, 2002). The histogram of the 345 remaining effect sizes is shown in Figure $2 .^{5}$

\footnotetext{
${ }^{5}$ A sensitivity analysis including the outliers showed that they have a non-negligible influence on the final results. The inclusion of the outliers does not change the signs of the meta-regression coefficients, but changes their significance level. Furthermore, the goodness of fit is better once the outliers are excluded.
} 


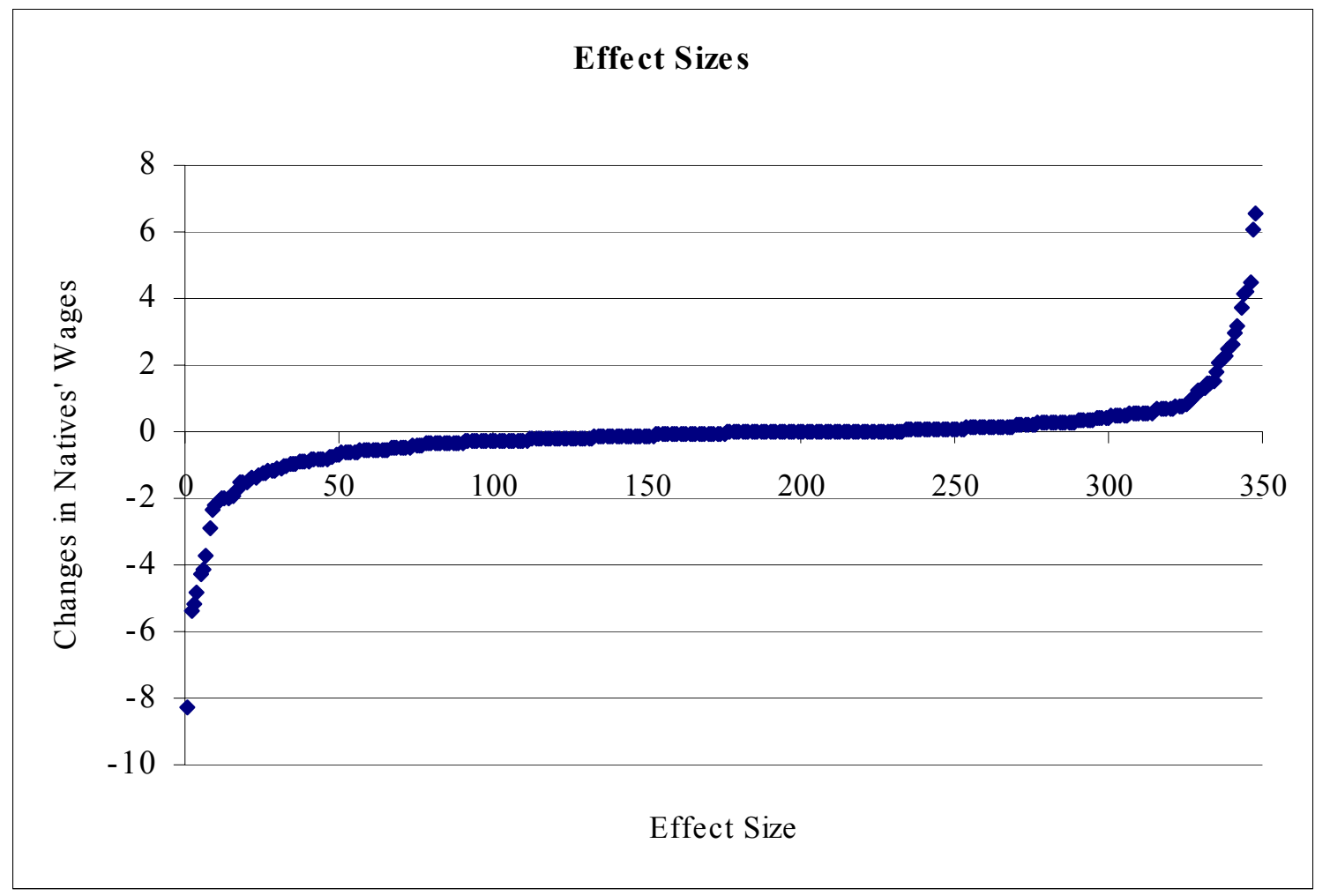

Figure 1: Effect sizes ordered by size

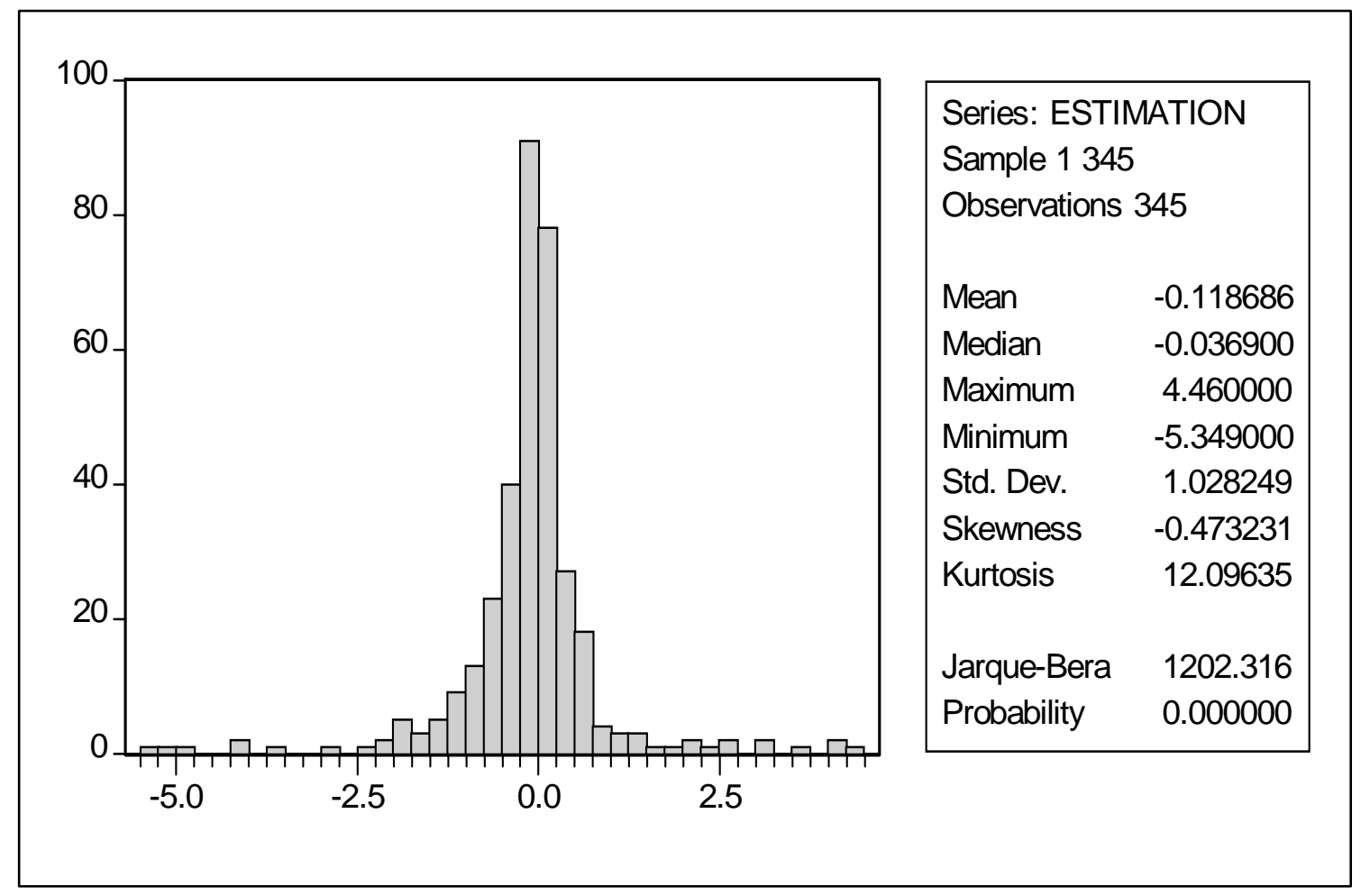

Figure 2: Distribution of the effect sizes after omitting the outliers

The first row of Table 2 shows the average, standard deviation, minimum and maximum value of the effect sizes included in the analysis. The overall mean is 
-0.119. This implies that if immigrants as a proportion of the labour force doubled from being one out of twenty workers to being one out ten workers, the natural logarithm of average wage in the local labour market would decrease by 0.00595 , i.e. wages would decrease by only about 0.6 percent. The example illustrates that, on average across all studies, the effect of immigration on wages is very small.

\section{Table 2: Descriptive Statistics}

\begin{tabular}{|c|c|c|c|c|c|c|}
\hline \multirow{2}{*}{ Total sample } & & \multirow{2}{*}{$\frac{\text { No. }}{345}$} & \multicolumn{2}{|c|}{ Mean Std. Dev. } & \multirow{2}{*}{$\begin{array}{l}\text { Min } \\
-5.349\end{array}$} & \multirow{2}{*}{$\begin{array}{l}\text { Max } \\
4.460\end{array}$} \\
\hline & & & -0.119 & 1.028 & & \\
\hline \multirow{3}{*}{ Size of Labour Market Area } & Large Areas & 94 & -0.166 & 0.995 & -2.900 & 3.700 \\
\hline & Country Areas & 48 & -0.351 & 1.580 & -5.349 & 4.170 \\
\hline & Small Areas ${ }^{(\#)}$ & 203 & -0.042 & 0.863 & -4.250 & 4.460 \\
\hline \multirow[t]{3}{*}{ Country } & $\mathrm{US}^{(\#)}$ & 234 & -0.157 & 0.821 & -4.250 & 4.460 \\
\hline & EU & 75 & -0.054 & 1.563 & -5.349 & 4.170 \\
\hline & Other Countries & 36 & -0.006 & 0.839 & -1.966 & 2.638 \\
\hline \multirow[t]{2}{*}{ Definition of Labour Market } & t Areas ${ }^{(\#)}$ & 83 & -0.128 & 1.891 & -5.349 & 4.460 \\
\hline & Areas and Occupation & 262 & -0.116 & 0.519 & -2.225 & 2.638 \\
\hline \multirow[t]{2}{*}{ Estimator } & Not Instrumented & 261 & -0.111 & 0.709 & -2.317 & 4.460 \\
\hline & Instrumented $^{(\#)}$ & 84 & -0.142 & 1.676 & -5.349 & 4.170 \\
\hline \multirow[t]{2}{*}{ Transformation of the Data } & First Difference ${ }^{(\#)}$ & 84 & -0.319 & 0.680 & -2.900 & 0.913 \\
\hline & No Transformations & 261 & -0.054 & 1.111 & -5.349 & 4.460 \\
\hline \multirow[t]{3}{*}{ Affected Group: Gender } & $\operatorname{Men}^{(\#)}$ & 129 & -0.182 & 1.424 & -5.349 & 4.460 \\
\hline & Women & 30 & -0.057 & 0.668 & -1.506 & -0.057 \\
\hline & Both Genders & 186 & -0.085 & 0.698 & -4.250 & 2.638 \\
\hline \multirow[t]{3}{*}{ Affected Group: Skill Level } & High Skill & 29 & 0.155 & 0.949 & -1.243 & 4.170 \\
\hline & Low Skill $^{(\#)}$ & 82 & -0.215 & 1.402 & -5.349 & 3.700 \\
\hline & All Skills & 234 & -0.119 & 0.870 & -4.250 & 4.460 \\
\hline \multirow[t]{3}{*}{ Affected Group: Sub-Group } & Immigrants & 72 & -0.392 & 0.798 & -4.250 & 0.368 \\
\hline & Natives $^{(\#)}$ & 267 & -0.046 & 1.081 & -5.349 & 4.460 \\
\hline & Natives and Immigrants & 6 & -0.064 & 0.432 & -0.555 & 0.551 \\
\hline \multirow[t]{3}{*}{ Immigrants' Skills } & High Skill & 41 & -0.122 & 0.589 & -1.970 & 0.913 \\
\hline & Low Skill $^{(\#)}$ & 28 & -0.003 & 0.104 & -0.255 & 0.234 \\
\hline & All Skills & 276 & -0.130 & 1.127 & -5.340 & 4.460 \\
\hline \multirow[t]{2}{*}{ International Trade } & Accounted for & 16 & -0.118 & 0.263 & -0.931 & 0.254 \\
\hline & Not Accounted for ${ }^{(\#)}$ & 329 & -0.119 & 1.052 & -5.349 & 4.46 \\
\hline \multirow[t]{2}{*}{ Approach } & Factor & 101 & -0.043 & 0.282 & -2.317 & 0.551 \\
\hline & Area $^{(\#)}$ & 244 & -0.150 & 1.209 & -5.349 & 4.460 \\
\hline \multirow[t]{3}{*}{ Definition of Immigrants } & Recent Immigrants & 86 & -0.061 & 1.272 & -4.250 & 4.460 \\
\hline & Ethnicity & 20 & 0.351 & 0.612 & -1.243 & 1.547 \\
\hline & Other $^{(\#)}$ & 239 & -0.179 & 0.947 & -5.349 & 4.170 \\
\hline \multirow[t]{6}{*}{ Definition of Wages } & Annual & 103 & -0.180 & 0.467 & -2.225 & 1.134 \\
\hline & Monthly & 24 & 0.376 & 1.403 & -2.900 & 3.700 \\
\hline & Weekly ${ }^{(\#)}$ & 132 & -0.108 & 0.674 & -2.074 & 2.638 \\
\hline & Daily & 18 & -0.358 & 0.167 & -0.358 & 0.368 \\
\hline & Hourly & 65 & -0.213 & 1.872 & -5.349 & 4.460 \\
\hline & No details & 3 & -0.940 & 1.193 & -2.317 & -0.201 \\
\hline
\end{tabular}

(\#) These are used as reference categories in the following regressions

The key question is to what extent this is true of all studies or whether there is some systematic variation in effect sizes across studies. The available studies differ in a number of ways, some of which may matter for the results. The study features that we want to analyse are listed in Table 2. These are all categorical variables, and the 
sample averages, standard deviations, minimum and maximum values corresponding to different classifications of observations are also reported in Table 2. Such classifications will be used to determine the independent dummy variables - also called moderator variables - for a meta-regression analysis. The table shows that almost all sample means suggest a small but negative effect of immigration on wages. Furthermore, a number of study features (such as the country for which the study was conducted) may be expected to have an impact on the effect sizes, as sample means vary strongly between the different categories of the study feature.

To assess the statistical significance of the variation in effect sizes across different categories for each study feature, we need to take the possible interactions between study features into account. Thus, noticeable differences between study results that we may detect by means of the univariate comparison of effect sizes in Table 2, may no longer show up in a multivariate context. It is therefore preferable to assess the impact of study characteristics by means of regression techniques.

\section{Meta-Regression Analysis}

We use the statistical tools of meta-analysis to further investigate the relationships between research design in measuring the wage impact of immigration and the empirical findings. Detailed discussions of the various techniques that are available can be inter alia found in Cooper and Hedges (1994) and Sutton et al. (2000).

As was already clear from the discussion of the previous sections, the effect sizes included in our database are computed for different countries, and use different definitions of immigrants and natives (e.g., in terms of gender and skills). They also differ in terms of the statistical approach, functional forms and estimators used to compute the effect of immigration. Such differences are likely to cause heterogeneity of the effect sizes. A test of the hypothesis that studies share a common population effect size uses the following homogeneity statistic (Shadish and Haddock, 1994, p.266):

$$
Q=\sum_{i=1}^{K}\left[\left(b_{i}-\bar{b}\right)^{2} /\left(v_{i}\right)\right]
$$

where $\bar{b}$. is the weighted average of the so-called effect sizes, which are here the estimates $b_{1}, b_{2}, \ldots, b_{K}$, of the parameters $\beta_{1}, \beta_{2}, \ldots, \beta_{K}$, weighted by the inverses of the estimated variances $v_{1}, v_{2}, \ldots, v_{K}$ :

$$
\bar{b}=\frac{\sum_{i=1}^{K} b_{i} / v_{i}}{\sum_{i=1}^{k} 1 / v_{i}}
$$


Homogeneity of the sample implies a common effect size: $\beta_{1}=\beta_{2}=\ldots=\beta_{K}=\beta$. If $Q$ exceeds the upper-tail critical value of the chi-square distribution with $K-1$ degrees of freedom, the observed variance in estimated elasticities is greater than what we would expect by chance if all studies shared the same 'true' parameter. When within-study sample sizes are rather large, $Q$ is likely to be rejected even when the individual effect sizes do not differ much, particularly when we have a large sample of observations (345, as in our case). The best way to account for heterogeneity is then to use regression techniques. In our meta-sample the $Q$-test for heterogeneity has a large value of 131296 which is highly significant ( $\chi^{2}$ with 343 degrees of freedom). The result of the test clearly indicates that differences across our effect sizes are not only due random error in the original estimations.

We model such heterogeneity of effect sizes by means of meta-regressions. The moderator variables of the regressions correspond to the groupings of effect sizes illustrated in Table 2. The regression results are computed with 344 effect sizes, and are shown in Table $3 .^{6}$

A key question of every meta-analysis is the extent to which the obtained sample of effect sizes may be considered representative of the population of studies. Because of the tendency of authors, referees and editors to favour the publication of statistically significant results, the sample of studies and, to a lesser extent of effect sizes, is likely to be biased toward more significant results (Stanley et al., 2004). We try to reduce the impact of publication bias in two ways. Firstly, since conventional wisdom suggests that publication bias is more likely in published than in unpublished analyses, we include in our meta-database both published and unpublished studies. Secondly, if we assume that authors choose the significant results that conform to their theories as their preferred model specification, but nevertheless publish also (some of) their nonsignificant results, then the effect of publication bias should be mitigated by sampling all estimates published in each primary study. For this reason we adopt the technique of multiple sampling by including in our analysis all effect sizes computed in each primary study.

We test for publication bias by using one of the tests suggested by Card and Krueger (1995), through assessing the relationship between the effect sizes to their standard errors. If there is publication bias, and significant effect sizes are more likely to be published, the ratios of effect sizes divided by their standard errors will bunch around two. Like Ashenfelter et al. (1999), we simultaneously correct for the problem of heterogeneity of the effect sizes by adding moderator variables to the regression testing for publication bias. $^{7}$

The results of this test are shown in the first column of Table 3. The model is estimated by means of OLS. ${ }^{8}$ If publication bias were present, we would expect an

\footnotetext{
${ }^{6}$ The omitted observation had a reported standard error of 0.000 .

${ }^{7} \mathrm{We}$ also computed alternative tests, such as the ones suggested by Florax (2002b) and Stanley et al. (2004), without finding, however, a conclusive evidence of publication bias by means of these tests.

${ }^{8}$ All estimations have been done with Stata 7.
} 
abundance of published $t$ statistics of around two, i.e., proportionality between effect sizes and their standard errors. In the regression shown in column (1) of Table 3 the standard error of the effect size is not significant at any conventional level, thus suggesting that publication bias is not a major issue in our sample. In the absence of publication bias, the standard error can be omitted from the regression.

Column (2) of Table 3 shows the resulting meta-regression estimated by means of OLS. Such an approach gives equal weight to each effect size. A common practice in meta-regression analysis is to weigh each effect size by the inverse of its standard error, in order to give higher weights to those effect sizes that are more precise, i.e. have a lower variance. Effectively, this is the multiple regression equivalent of equation (4). Furthermore, weighting each observation in regression by the inverse of the estimated standard deviation has the effect of reducing the residual unexplained heterogeneity (Thompson, 2001). The results of this approach are shown in column (3) of Table 3. The estimates are computed by means of weighted least squares (WLS). A weakness of this approach is that WLS are inefficient when the weights are correlated with the disturbances (Greene, 2003) or when the effect sizes are correlated with each other (Gleser and Olkin, 1994). A further problem of this approach concerns the comparability of the standard errors of the primary studies, since standard errors that are 'robust' for heteroskedasticity are, ceteris paribus, higher than those neglecting such a misspecification. This issue will be elaborated further below.

In the medical field a common alternative to OLS and WLS estimators is the mixedeffect model, typically estimated by means of Maximum Likelihood (ML) estimators. The mixed-effect model is generally preferred when part of the heterogeneity is not captured by the explanatory variables included in the model (see, for example, Sutton et al., 2000). ${ }^{9}$ The results of the mixed effect model are shown in column (4) of Table 3. Also this approach has a drawback: it assumes additivity of effect sizes' variances. In economic meta-analyses, often characterised by multiple observations from each study, this additivity assumption might not hold. In such a situation, the obtained estimates might be misleading.

With only few exceptions, the results of the three estimation techniques seem to be rather consistent, as shown in Table 3.

\footnotetext{
${ }^{9}$ When the aim of the analysis is to verify the effect of certain study characteristics on the estimated effect sizes, rather than reaching a high goodness of fit, the OLS or WLS approaches might be preferred for their robustness.
} 
Table 3: Meta Regressions

\begin{tabular}{|c|c|c|c|c|c|c|c|}
\hline Study Feature & Categories & $\begin{array}{c}(1) \\
\text { OLS }\end{array}$ & $\begin{array}{c}(2) \\
\text { OLS }\end{array}$ & $\begin{array}{c}(3) \\
\text { WLS }^{a}\end{array}$ & $\begin{array}{c}(4) \\
\text { Mixed Effect }\end{array}$ & $\begin{array}{c}(5) \\
\text { WLS }^{b}\end{array}$ & $\begin{array}{c}(6) \\
\text { WLS }^{c}\end{array}$ \\
\hline \multirow[t]{2}{*}{ Transformation of the Data } & No Transformation & $\begin{array}{c}0.3903 * \\
(0.2152)\end{array}$ & $\begin{array}{c}0.3995 * \\
(0.2113)\end{array}$ & $\begin{array}{r}-0.1212 * * * \\
(0.0302)\end{array}$ & $\begin{array}{r}-3.2254 \\
(3.8190)\end{array}$ & - & - \\
\hline & First Differences & - & - & - & - & - & - \\
\hline \multirow[t]{2}{*}{ Estimator } & No Control for Endogeneity & $\begin{array}{c}0.2735^{*} \\
(0.1486)\end{array}$ & $\begin{array}{c}0.3091 * \\
(0.1665)\end{array}$ & $\begin{array}{r}0.0007 \\
(0.0008)\end{array}$ & $\begin{array}{r}6.0591 * * \\
(3.0243)\end{array}$ & $\begin{array}{r}0.2592 * * * \\
(0.0288)\end{array}$ & $\begin{array}{r}0.0002 \\
(0.0002)\end{array}$ \\
\hline & Instrumental Variables & - & - & - & - & - & - \\
\hline \multirow[t]{2}{*}{ Approach } & Factor Allocation Model & $\begin{array}{r}0.9104 * * \\
(0.4424)\end{array}$ & $\begin{array}{r}0.8875 * * \\
(0.4390)\end{array}$ & $\begin{array}{r}0.2058 * * * \\
(0.0402)\end{array}$ & $\begin{array}{r}24.9809 * * * \\
(8.3743)\end{array}$ & $\begin{array}{r}0.7949 * * * \\
(0.0659)\end{array}$ & $\begin{array}{r}0.0161 * * * \\
(0.0046)\end{array}$ \\
\hline & Area Approach & - & - & - & - & - & - \\
\hline \multirow[t]{3}{*}{ Country } & $\mathrm{EU}$ & $\begin{array}{r}-1.4350^{*} \\
(0.8205)\end{array}$ & $\begin{array}{r}-1.4216^{*} \\
(0.8129)\end{array}$ & $\begin{array}{r}-1.3947 * * * \\
(0.1050)\end{array}$ & $\begin{array}{r}-15.8781 * * \\
(7.9128)\end{array}$ & $\begin{array}{r}-1.4289 * * * \\
(0.1489)\end{array}$ & $\begin{array}{r}-0.3218 * * * \\
(0.0166)\end{array}$ \\
\hline & Other Countries & $\begin{array}{r}0.2480 \\
(0.4866)\end{array}$ & $\begin{array}{r}0.2698 \\
(0.4951)\end{array}$ & $\begin{array}{r}-0.4290 * * * \\
(0.0868)\end{array}$ & $\begin{array}{r}-3.4594 \\
(9.9071)\end{array}$ & $\begin{array}{r}0.0779 \\
(0.0901)\end{array}$ & $\begin{array}{r}-0.1148 * * * \\
(0.0132)\end{array}$ \\
\hline & USA & - & - & - & - & - & - \\
\hline \multirow[t]{3}{*}{ Size of Labour Market Area } & Country Areas & $\begin{array}{r}-0.2561 \\
(0.3467)\end{array}$ & $\begin{array}{r}-0.3275 \\
(0.3418)\end{array}$ & $\begin{array}{r}-0.0634 \\
(0.0742)\end{array}$ & $\begin{array}{r}0.8223 \\
(10.0360)\end{array}$ & $\begin{array}{r}-0.3069 * * * \\
(0.0585)\end{array}$ & $\begin{array}{r}0.0181 \\
(0.0111)\end{array}$ \\
\hline & Large Areas & $\begin{array}{r}-0.0440 \\
(0.2964)\end{array}$ & $\begin{array}{r}-0.1192 \\
(0.2801)\end{array}$ & $\begin{array}{r}0.0305 * * \\
(0.0120)\end{array}$ & $\begin{array}{r}11.2213 * * \\
(5.6386)\end{array}$ & $\begin{array}{r}-0.1548 * * * \\
(0.0495)\end{array}$ & $\begin{array}{r}0.0128 * * * \\
(0.0020)\end{array}$ \\
\hline & Small Areas & - & - & - & - & - & - \\
\hline \multirow[t]{2}{*}{ Definition of Labour Market } & Area and Occupation-Specific & $\begin{array}{r}-0.5865 \\
(0.3564)\end{array}$ & $\begin{array}{r}-0.5068 \\
(0.3326)\end{array}$ & $\begin{array}{r}-0.9811 * * * \\
(0.0132)\end{array}$ & $\begin{array}{c}-21.5778 * * * \\
(4.8831)\end{array}$ & $\begin{array}{r}-0.4080 * * * \\
(0.0603)\end{array}$ & $\begin{array}{r}-0.2356 * * * \\
(0.0025)\end{array}$ \\
\hline & Area Only & - & - & - & - & - & - \\
\hline \multirow[t]{2}{*}{ International Trade } & Accounted for & $\begin{array}{r}-1.0291 \\
(0.7911)\end{array}$ & $\begin{array}{r}-1.0343 \\
(0.7907)\end{array}$ & $\begin{array}{r}-1.0787 * * * \\
(0.2280)\end{array}$ & $\begin{array}{r}21.9220 * * \\
(11.1057)\end{array}$ & $\begin{array}{r}-1.1506^{* * * *} \\
(0.1713)\end{array}$ & $\begin{array}{r}-0.0890 * * \\
(0.0370)\end{array}$ \\
\hline & Not Accounted for & - & - & - & - & - & - \\
\hline
\end{tabular}




\begin{tabular}{|c|c|c|c|c|c|c|c|}
\hline Study Feature & Categories & $\begin{array}{c}(1) \\
\text { OLS }\end{array}$ & $\begin{array}{c}(2) \\
\text { OLS }\end{array}$ & $\begin{array}{c}(3) \\
\text { WLS }^{a}\end{array}$ & $\begin{array}{c}(4) \\
\text { Mixed Effect }\end{array}$ & $\begin{array}{c}(5) \\
\text { WLS }^{b}\end{array}$ & $\begin{array}{c}(6) \\
\text { WLS }^{\mathrm{c}}\end{array}$ \\
\hline \multirow[t]{3}{*}{ Affected Group } & Immigrants & $\begin{array}{r}-0.6851 * * * \\
(0.1456)\end{array}$ & $\begin{array}{r}-0.6981 * * * \\
(0.1563)\end{array}$ & $\begin{array}{r}-0.0034 * * * \\
(0.0011)\end{array}$ & $\begin{array}{r}-8.2090 * * * \\
(3.0455)\end{array}$ & $\begin{array}{r}-0.5826 * * * \\
(0.0258)\end{array}$ & $\begin{array}{r}-0.0008 * * * \\
(0.0002)\end{array}$ \\
\hline & Natives and Immigrants Together & $\begin{array}{r}0.1536 \\
(0.1590)\end{array}$ & $\begin{array}{r}0.1246 \\
(0.1605)\end{array}$ & $\begin{array}{r}0.2310 * * \\
(0.0904)\end{array}$ & $\begin{array}{r}0.6067 \\
(8.4522)\end{array}$ & $\begin{array}{r}0.2725 * * * \\
(0.0300)\end{array}$ & $\begin{array}{r}0.0418 * * * \\
\quad(0.0145)\end{array}$ \\
\hline & Natives & - & - & - & - & - & - \\
\hline \multirow[t]{3}{*}{ Type of Immigrants } & Recent Immigrants & $\begin{array}{r}0.5698 \\
(0.4269)\end{array}$ & $\begin{array}{r}0.5137 \\
(0.4011)\end{array}$ & $\begin{array}{r}0.2601 * * * \\
(0.0900)\end{array}$ & $\begin{array}{r}10.9624 \\
(7.6413)\end{array}$ & $\begin{array}{r}0.4699 * * * \\
(0.0698)\end{array}$ & $\begin{array}{r}0.0759 * * * \\
\quad(0.0135)\end{array}$ \\
\hline & Ethnicity & $\begin{array}{r}2.2426 * * \\
(0.9582)\end{array}$ & $\begin{array}{r}2.1881 * * \\
(0.9347)\end{array}$ & $\begin{array}{r}2.0076 * * * \\
(0.1068)\end{array}$ & $\begin{array}{r}42.0512 * * * \\
(11.6337)\end{array}$ & $\begin{array}{r}2.2505 * * * \\
(0.1650)\end{array}$ & $\begin{array}{r}0.4315 * * * * \\
(0.0171)\end{array}$ \\
\hline & Foreign born/Non-nationals & - & - & - & - & - & - \\
\hline \multirow[t]{3}{*}{ Immigrants' Skills } & High Skilled Immigrants & $\begin{array}{r}-0.0088 \\
(0.1221)\end{array}$ & $\begin{array}{r}-0.0009 \\
(0.1250)\end{array}$ & $\begin{array}{r}-0.0256 \\
(0.1170)\end{array}$ & $\begin{array}{r}-0.4124 \\
(5.2815)\end{array}$ & $\begin{array}{r}-0.0082 \\
(0.1270)\end{array}$ & $\begin{array}{r}-0.0040 \\
(0.0203)\end{array}$ \\
\hline & Immigrants of All Skills & $\begin{array}{r}-0.2576^{*} \\
(0.1362)\end{array}$ & $\begin{array}{r}-0.2675 * \\
(0.1371)\end{array}$ & $\begin{array}{r}-0.0221 \\
(0.0597)\end{array}$ & $\begin{array}{r}-1.8532 \\
(5.2978)\end{array}$ & $\begin{array}{r}-0.2132 \\
(0.1386)\end{array}$ & $\begin{array}{r}-0.0040 \\
(0.0101)\end{array}$ \\
\hline & Low Skilled Immigrants & - & - & - & - & - & - \\
\hline \multirow[t]{3}{*}{ Affected Skill Group } & High Skilled Workers & $\begin{array}{r}0.7547 * * * \\
(0.2900)\end{array}$ & $\begin{array}{r}0.7513 * * * \\
\quad(0.2897)\end{array}$ & $\begin{array}{r}-0.1416 \\
(0.2978)\end{array}$ & $\begin{array}{r}2.7970 \\
(4.4073)\end{array}$ & $\begin{array}{r}0.9781 * * * \\
\quad(0.2890)\end{array}$ & $\begin{array}{r}-0.0242 \\
(0.0560)\end{array}$ \\
\hline & Workers of All Skills & $\begin{array}{r}0.4926 * * * \\
(0.1341)\end{array}$ & $\begin{array}{r}0.5068 * * * \\
(0.1287)\end{array}$ & $\begin{array}{r}0.2227 \\
(0.2248)\end{array}$ & $\begin{array}{l}4.9467 * \\
(2.9475)\end{array}$ & $\begin{array}{r}0.5043 * * * \\
(0.1300)\end{array}$ & $\begin{array}{r}0.0420 \\
(0.0378)\end{array}$ \\
\hline & Low Skilled Workers & - & - & - & - & - & - \\
\hline \multirow[t]{3}{*}{ Gender of Affected Workers } & Women & $\begin{array}{r}0.0084 \\
(0.1475)\end{array}$ & $\begin{array}{r}0.0060 \\
(0.1479)\end{array}$ & $\begin{array}{r}-0.2535 \\
(0.2448)\end{array}$ & $\begin{array}{c}-5.4670 \\
(4.3825)\end{array}$ & $\begin{array}{r}0.0371 \\
(0.1502)\end{array}$ & $\begin{array}{r}-0.0590 \\
(0.0453)\end{array}$ \\
\hline & Both Genders & $\begin{array}{r}-0.1082 \\
(0.2574)\end{array}$ & $\begin{array}{r}-0.1189 \\
(0.2659)\end{array}$ & $\begin{array}{r}0.1029 \\
(0.4144)\end{array}$ & $\begin{array}{r}-8.2044 * * \\
(4.1148)\end{array}$ & $\begin{array}{r}-0.0762 \\
(0.1945)\end{array}$ & $\begin{array}{r}0.0366 \\
(0.0306)\end{array}$ \\
\hline & Men & - & - & - & - & - & - \\
\hline Definition of Wages & Annual & $\begin{array}{r}-0.4284 * * \\
(0.1895)\end{array}$ & $\begin{array}{r}-0.4439 * * \\
(0.1852)\end{array}$ & $\begin{array}{r}-0.0483 \\
(0.4383)\end{array}$ & $\begin{array}{r}-1.1803 \\
(5.3244)\end{array}$ & $\begin{array}{r}-0.2701 \\
(0.1703)\end{array}$ & $\begin{array}{r}-0.0047 \\
(0.0633)\end{array}$ \\
\hline
\end{tabular}




\begin{tabular}{|c|c|c|c|c|c|c|c|}
\hline \multicolumn{2}{|c|}{ Study Feature } & $\begin{array}{c}(1) \\
\text { OLS }\end{array}$ & $\begin{array}{c}(2) \\
\text { OLS }\end{array}$ & $\begin{array}{c}(3) \\
\text { WLS }^{a}\end{array}$ & $\begin{array}{c}(4) \\
\text { Mixed Effect }\end{array}$ & $\begin{array}{c}(5) \\
\text { WLS }^{b}\end{array}$ & $\begin{array}{c}(6) \\
\text { WLS }^{c}\end{array}$ \\
\hline \multirow{2}{*}{\multicolumn{2}{|c|}{ Monthly }} & $3.3227 * * *$ & $3.3601 * * *$ & 2.4917 & 5.6406 & $3.1855 * * *$ & 0.4115 \\
\hline & & $(1.0725)$ & $(1.0758)$ & $(3.7419)$ & $(10.3295)$ & $(1.1432)$ & $(0.6063)$ \\
\hline \multirow{2}{*}{\multicolumn{2}{|c|}{ Daily }} & 1.0489 & 1.0748 & 1.3890 & 10.1458 & $1.2833^{*}$ & 0.2952 \\
\hline & & $(0.7942)$ & $(0.7987)$ & $(1.7564)$ & (12.9090) & $(0.7580)$ & $(0.2715)$ \\
\hline \multirow{2}{*}{\multicolumn{2}{|c|}{ Hourly }} & -0.1520 & -0.1662 & 0.1178 & 10.0261 & -0.0558 & 0.0060 \\
\hline & & $(0.3987)$ & $(0.4024)$ & $(1.3462)$ & $(7.4207)$ & $(0.3529)$ & $(0.2011)$ \\
\hline \multirow{2}{*}{\multicolumn{2}{|c|}{ No Details }} & -1.1591 & -1.0817 & $-2.2886 * * *$ & $-52.3902 * * *$ & $-1.2752^{*}$ & $-0.4027 * * *$ \\
\hline & & $(0.7372)$ & $(0.7306)$ & $(0.6721)$ & $(13.6755)$ & $(0.6979)$ & $(0.0822)$ \\
\hline \multicolumn{2}{|r|}{ Weekly } & - & - & - & - & - & - \\
\hline Publication Bias: & Standard Error & $\begin{array}{r}-0.1439 \\
(0.3821)\end{array}$ & - & - & - & - & - \\
\hline \multicolumn{2}{|l|}{ Constant } & $\begin{array}{r}-0.4014 \\
(0.3321)\end{array}$ & $\begin{array}{r}-0.4777 * \\
(0.2644)\end{array}$ & $\begin{array}{r}0.6415 \\
(0.5492)\end{array}$ & $\begin{array}{r}4.4479 \\
(7.3063)\end{array}$ & $\begin{array}{r}-0.3515 \\
(0.2470)\end{array}$ & $\begin{array}{r}0.1497 * * * \\
(0.0543)\end{array}$ \\
\hline \multicolumn{2}{|l|}{ Observations } & 344 & 344 & 344 & 344 & 344 & 344 \\
\hline \multicolumn{2}{|c|}{ Correlation between observed and fitted effect sizes } & 0.5343 & 0.5325 & 0.1585 & 0.2795 & 0.5028 & 0.1576 \\
\hline
\end{tabular}

Notes: White-robust standard errors in parentheses; * significant at 10\%; ** significant at 5\%; *** significant at $1 \%$.

${ }^{a}$ WLS weighted by the inverse standard error of the effect sizes; ${ }^{b}$ WLS weighted by the assigned quality of the effect sizes; ${ }^{c}$ WLS weighted by the assigned quality of the effect sizes multiplied by the inverse of the standard errors of the effect sizes 
In an open labour market, adjustment processes such as native out-migration, trade and capital inflow might bias the estimation of the effect of immigration towards zero. As a result, the effect of these adjustment processes will be larger in small areas than in big areas (Card, 2001). Those studies focusing on small geographic areas are therefore more likely to miss a negative effect of immigration on native wages than those focusing on large areas (see also Borjas et al., 1997). The sample means in Table 2 show a bigger negative effect in large areas (such as US states or US large regions) than in smaller areas (such as SMSAs in the US). The OLS results suggest that the coefficient estimated for larger areas is more negative than the coefficient estimated in smaller areas, and that it is even more negative when the area coincides with a country: an entire country is - relatively speaking - the least open region. The largest immigration effects are indeed observed at the national level. However, the differences are not statistically significant, suggesting that such equilibrating factors might have only a long-run effect (see Borjas, 2001). The WLS (column 3) and the Mixed Effect estimators show instead, rather surprisingly, a positive and significant coefficient for the 'Large Areas' dummy.

Given that adjustment effects are expected to be stronger in countries with high rates of internal mobility, we might expect the effect sizes to be larger in countries with lower internal mobility. This would suggest, for example, that effect sizes would be larger in Europe (where geographical mobility is relatively low) than in the US (where it is high). The results in Table 3 confirm that the effect sizes estimated by studies focussing on the US seem to be significantly closer to zero than the ones estimated by studies focussing on the EU.

Different outcomes on the wage effect of immigration might be connected to different definitions of the labour markets. While in some studies the local labour market is only defined in terms of geographical areas, in other studies the local labour market is defined by two variables: geography and occupations/skills. Since the estimated effect sizes might be biased towards zero by the natives' outmigration, narrower definitions of local labour markets might result in higher biases. To calculate the effect of immigration on wages we should therefore not only adopt a counterfactual of zero migration of natives, but also of zero movement across occupations/skills. We therefore expect the effect sizes to be closer to zero when estimated on the basis of a narrower - area and occupation definition of labour markets. However, the results of Table 3 do not confirm such hypothesis.

Another source of underestimation of the effects of immigration can be found in the non-random distribution of immigrants across the labour market areas compared. If immigrants locate in those areas offering higher wages, then instrumental variables estimators are needed to correct for this endogeneity problem and therefore to avoid the estimation of a spurious relationship between wages and immigration (see Borjas, 1999, Friedberg and Hunt, 1995, and Card, 2001). The regressions suggest that those primary studies that did not use 
instrumental variable estimators tend to find less negative effect sizes. The results are almost always significant. However, endogeneity of immigrants' location decisions might be only a minor problem. Altonji and Card (1991) argue that immigrants tend to cluster where other immigrants of the same type are already located. In this case, immigrants' location might be dependent more on historical, than on economic reasons.

Friedberg and Hunt (1995) argue that factor price equalisation might cause an underestimation of the effect of immigration computed on cross-section data. Besides, Altonji and Card (1991) suggest that there is a need to first-difference the data in order to capture the short-run effects of immigration. The reason is that first-differenced data are probably less affected by city-specific unobserved characteristics that might influence immigrants' density and/or natives' outcomes. In this case the results seem to be rather inconclusive. The practice of computing first-differences of the original data might contribute only marginally to the reduction of the downward bias in the estimated effect of immigration. The reason for this result might be due to the data used in the primary studies. Since many primary studies use census data, the first differences are computed over five or ten-year periods, implicitly assuming such city-specific regional characteristics to remain constant over a rather long time period.

The female labour force participation rate seems to react more to changes in wages and in unemployment rates than the male labour force participation rate (see, e.g., Borjas, 1996). As a result, the effect of immigration on wages is probably more clearly estimated for men than for women. In such case we would expect a more negative effect of immigration on male than on female workers. Some authors (e.g., Borjas, 2003) suggest that immigrants are likely to be substitutes for low-skill natives and for females, while they are likely to complement highly skilled natives. We would then expect immigrants to have a bigger impact on females than on males, and on low- rather than on high-skilled workers. Table 2 shows a more negative wage effect on males - rather than on females - and on low-skill - rather than on highly skilled - workers. ${ }^{10}$ However, the regression results in Table 3 show that the coefficients of the genderdummies tend to be not significant, suggesting that immigration has the same effect on both males and females. Therefore, the gender differences highlighted in Table 2 might be due to different skill compositions of males and females groups. On the other hand, the regression coefficients clearly suggest that immigrants are more in competition - and therefore to have a bigger depressing effect - on low- than high-skilled native workers. Therefore, our finding of insignificant coefficients of the 'Area and Occupation' dummy, together with the significant coefficients of the 'Natives' Skills' dummies tend to support Borjas's (2003) claim that a careful definition of workers' skills should allow the solution of the problem of neglected equalising factors.

\footnotetext{
${ }^{10}$ Skills are defined in terms of education and/or occupation (blue versus white collars) and/or experience.
} 
As noted earlier, narrative surveys of the empirical literature conclude that the effect of immigration on natives' wages is rather small (see, e.g., Borjas, 2003 and Friedberg and Hunt, 1995). In particular, Friedberg and Hunt (1995) compare the crowding effects on labour market of baby-boomers as estimated by Welch (1979), with the empirical findings of the immigration literature. While the effect of baby-boomers generated a twelve percent drop in the wages of competing workers, the effect of immigration appears to be negligible (usually less than one percent). Such a difference, which might seem rather surprising, is probably due to the difference in the extent of workers substitutability. Welch's (1979) baby-boomers are likely to be a close substitutes for somewhat earlier or later cohorts, and therefore in strong competition with each other. Because of certain characteristics, such as language skills, education obtained in the home country and culture, immigrants might not be close substitutes for native workers. As a result, immigrants might not decrease natives' wages significantly. Although our meta-analysis does not allow the identification of the exact effect of immigration on natives' wages, it can, nevertheless, provide an interesting interpretation of the small effect generally found by the empirical literature. The results in Table 3 clearly indicate that immigrants have a significantly bigger depressing effect on wages of other immigrants than on natives' wages.

Though the majority of studies assume that immigrants are low-skilled workers, Friedberg (2001) and Hunt (1992) analyse the effect of immigrants (Russians in Israel and French repatriates from Algeria) who are relatively highly skilled. Furthermore, Bauer (1998) and Greenwood et al. (1997) estimate the effect of immigrants of different skill levels. The results of Table 3 show that the effect of high-skilled immigrants is not significantly different than the effect of lowskilled ones.

Winter-Ebmer and Zimmermann (1998) and Hofer and Huber (2003) argue that the observed effect of immigration on wages might be underestimated because of the effect of international trade on the allocation of labour across sectors. In Table 2 the mean effect size computed from studies that explicitly account for the effect of foreign trade is almost identical to the mean effect size computed from those studies that neglect such effect, although the number of observations on the former was rather small. On this issue, the results of Table 3 are rather inconclusive.

According to Borjas et al. (1996) and to Friedberg (2001), the studies applying the factor proportions approach tend to find a larger wage effect of immigration than those applying the area approach. The evidence in Table 3 contradicts Borjas's et al. (1996) and Friedberg's (2001) remark, and clearly suggests that the factor approach tends to estimate effect sizes that are significantly closer to zero. This issue will be developed further below. 
We also analyse the effect of different definitions of immigrants by comparing effect sizes focusing on recent immigrants and on workers' ethnicity. Recent immigrants are here defined as foreign born workers who have resided less than 10 years in the host country. The effect on native wages of recent immigrants may be expected to be less than the effect of earlier immigrants, since the latter have become, through the process of adaptation, closer substitutes to natives. The definition of ethnicity of migrants may involve not only the identification of the worker's birthplace, but also the identification of his/her parents' birthplace (Hartog and Zorlu, 2002). Obviously, the first definition of immigrants is much narrower than the second one. The majority of studies, however, define immigrants on the basis of their birthplace - 'foreign born' is the typical definition of US studies - or on the basis of their nationality. This last definition - 'non-nationals' - is typical of EU studies. While estimates for recent immigrants and for immigrants of an ethnicity other than the dominant native one could be identified, the definitions of foreign born and non-nationals are overlapping for EU and US studies. For this reason we grouped them in the same category. The meta-regression suggests that the effect sizes estimating the impact of recent immigrants tend to have a positive sign, but the effect is not always significant. The regression also suggests that primary studies analysing the effect of ethnic immigrants generally estimate effect sizes that are less negative (weaker) than the average. However, since only one study in our sample defines immigrants in terms of ethnicity, this result might also be due to other characteristics that are specific to this study.

We finally computed separate mean effect sizes for those studies focusing on annual, monthly, weekly, daily or hourly wages. We would expect that if an immigration shock lowers hourly wages, and the labour supply relationship of natives is upward sloping, the effect on annual earnings of natives is greater than on hourly wages. ${ }^{11}$ Although there is some variation, the wage impact does appear to be significantly more positive for monthly and significantly negative for annual, compared to weekly, wages. This is consistent with Table 2, and suggests a backward bending supply curve rather than an upward sloping one. If hourly wages are reduced, but monthly earnings are reduced less, workers must have increased the total hours of work per month.

As previously mentioned, two competing approaches based on different hypotheses, assumptions and methodologies - the factor proportions and area approaches - can be used to analyse the effect of immigration on natives. The differences between the two approaches might raise doubts about their comparability in the same meta-analysis. It can be argued that the use of one dummy - the Factor Approach dummy - might be too simplistic and therefore insufficient to model such differences. For this reason we re-estimated model (2)

\footnotetext{
${ }^{11}$ In our sample of studies the definition of wages is quite heterogeneous. We therefore suspect that these last dummy variables might capture effects different than the ones that they intend to measure. For this reason the coefficients of such variables have to be interpreted cautiously.
} 
of Table 3 separately for the factor and area approaches. ${ }^{12}$ The model results computed on the 244 effect sizes obtained from those primary studies applying the area approach are very similar to those already shown in Table 3 . However, the model computed on the remaining 100 effect sizes obtained from those primary studies applying the factor approach does not show many significant coefficients. Furthermore, because the high homogeneity of such studies, many of the dummy variables identified in Table 2 and in Table 3 could not be estimated. We can, therefore, conclude that the factor approach is less informative in identifying the wage impact of immigration.

The second sensitivity analysis aims at investigating the effect of the data transformation that we applied to make the effect sizes comparable, see equation (2). We therefore re-estimated the model separately for the two groups of primary studies: those from which we directly collected the effect sizes used in the meta-analysis, and those for which data transformation was needed. ${ }^{13}$ The regression computed on the 196 observations for which no pre-processing was needed show coefficients that are similar to the ones estimated in Table 3 , thus generally corroborating - sometimes strengthening - our previous conclusions. The model computed on the remaining 148 effect sizes, for which transformation was needed, does not show many significant coefficients. This may be due to imprecision in the estimates of sample means that we gauged from the publications in order to convert elasticities to effect sizes.

As a third sensitivity analysis we estimate our model after weighting each effect size by a measure of its quality. A general criticism to meta-analysis relates to the practice of giving equal importance to all primary studies, independently on their quality. As a result, the presence of bad quality estimations among the effect sizes of the meta-sample might bias the coefficients of the meta-regression. Woodward and Wui (2001) attempt to control for study quality by including specific dummy variables to differentiate between studies with high- and lowquality data, econometrics, etc. We use here a different approach. To lower the influence of low-quality primary studies - or effect sizes - we can weigh each meta-observation, thereby introducing of course some subjectivity into the analysis.

We compute four groups of quality indices. The first group gives a higher weight (equal to two) to those primary studies published in good quality journals and a lower weight (equal to one) to the other studies. In this case, all effect sizes belonging to the same primary study have the same weight. Similarly, those primary studies reporting robust standard errors generally seem to be of better quality than those that report non-corrected standard errors. For this reason the second group of weights gives a higher value (equal to two) to those effect sizes for which robust standard errors are reported. All other effect sizes have weights

\footnotetext{
${ }^{12}$ The results are not presented here but are available from the authors on request.

${ }^{13}$ The results are not presented here but are available from the authors on request.
} 
equal to one. Since computation (or not) of robust standard errors is a practice that is usually applied to all effect sizes estimated in the same primary study, again all effect sizes collected from the same primary study have also the same weight. The third group of weights intends to distinguish between the econometric approaches used. We give lower weight (equal to one) to those effect sizes estimated by OLS and higher weight (equal to two) to all effect sizes using more advanced estimators (i.e. those that control for endogeneity of immigration). Finally, the fourth group of weights gives higher weights (equal to two) to those effect sizes computed on first-differenced data and lower weights (equal to one) to those effect sizes computed on data on levels. Finally, the aggregate weights of each effect size are computed as the sum of the four separate groups of weights. The minimum aggregate weight is therefore four, while the maximum weight is eight.

The model in which each observation is weighted by its quality has been estimated using WLS. The results are shown in column (5) of Table 3. They are generally consistent with the important effects identified earlier. Also, we now find the expected relationship between the effect sizes and the size of the labour market area. The effect is significantly more negative for large areas than for small areas and, in turn, more negative for country areas than for large areas.

A natural step forward in the estimations is to combine the two WLS estimators. The results of column (6) are computed by means of WLS with weights equal to the product of the quality weights - as in column (5) - and the inverse standard errors of the effect sizes, as in column (3). Such a combination is expected to (partially) overcome the above-mentioned problem of comparability of 'robust' and 'non-robust' standard errors of the primary studies. The final regression results are generally consistent with the previous estimations.

Some results are robust over all meta-regression model specifications and estimation techniques. First, immigrants have a more depressing effect on wages of other immigrants than on wages of natives. The effect of immigration is similar for both genders, and does not seem to depend much on the immigrants' skills. Furthermore, low-skilled natives seem to be more negatively affected by immigration than high-skilled natives. This suggests a generally low substitutability between natives and immigrants, and that such degree of substitutability is higher with low-skilled natives, but does not depend on gender.

The regressions also confirm that the effect sizes estimated for EU countries are more negative than the ones estimated for the US, and that the effect sizes estimated by means of the factor approach are closer to zero than the ones estimated using the area approach. 


\section{Conclusions}

In this paper we have investigated the result of previous studies analysing the effect of immigration on natives' wages. As already noted by Borjas (2003), the estimated effect of immigration on the wage of native workers varies widely from study to study and sometimes even within the same study.

By means of meta-analysis techniques we statistically summarised 344 estimates collected from a sample of eighteen studies computing the percentage change in the wage of a native worker with respect to a one percentage point increase in the ratio of immigrants over native workers. Issues such as publication bias and study quality were addressed. Overall, the effect is very small. A one percentage point increase in the proportion of immigrants in the labour force lowers wages across the investigated studies by only 0.119 percent.

We found that the negative impact of immigration on wages is larger in EU countries than in the US. However, such differences should not be attributed to the geographical size of the local labour markets that constitute the observations in the primary studies. We also found that, other things equal, immigrants are more in competition with other immigrants than with natives. However, immigration does not appear to have different effects on female than on male workers.

Much work remains to be done on assessing the impact of immigration on labour markets. The broad conclusion of 22 years of research since Grossman's (1982) estimates is that the impact of immigration on wages is statistically significant but quantitatively small. This has been indeed confirmed by our meta-analysis. The challenge for further research is to identify and separate carefully the many adjustment processes that have given rise to this observation. Research on capital flows, sectoral change, economies of scale and technological change induced by immigration would need high priority. Moreover, it is likely that the short-run impact of immigration differs strongly from the medium and long-term impact, so that dynamic analysis with time series data on labour markets and longitudinal data on workers should now replace the conventional cross-sectional area and factor proportions approaches.

\section{References}

Addison, T. and Worswick, C. (2002) The Impact of Immigration on the Earnings of Natives: Evidence from Australian Micro Data, The Economic Record, 78 (1) 68-78.

Altonji, J. G. and Card, D. (1991) The Effect of Immigration on the Labor Market Outcomes of Less-Skilled Natives, in Immigration, Trade and the Labor Market, ed. by J. M. Abowd and R. B. Freeman: NBER, 201-234. 
Ashenfelter, O., Harmon, C. and Oosterbeek, H. (1999) A Review of Estimates of the Schooling/Earnings Relationship, with Tests for Publication Bias, Labour Economics, 6 (4) 453-470.

Bauer, T. (1998) Do Immigrants Reduce Natives' Wages? Evidence from Germany, Dept. of Economics Rutgers University Working Paper No. 1998/02.

Borjas, G. (2001) Does Immigration Grease the Wheels of Labor Market?, Brookings Papers on Economic Activity, 1:2001 69-133.

Borjas, G. J. (1987) Immigrants, Minorities, and Labor Market Competition, Industrial and Labor Relations Review, 40 (3) 382-392.

Borjas, G. J. (1996) Labor Economics. New York: McGraw Hill.

Borjas, G. J. (1999) The Economic Analysis of Immigration, in Handbook of Labor Economics, ed. by O. Ashenfelter and D. Card: North Holland, 1697-1760.

Borjas, G. J. (2003) The Labor Demand Curve Is Downward Sloping: Reexamining the Impact of Immigration on the Labor Market, Quarterly Journal of Economics, 118 (4) 1335-1374.

Borjas, G. J., Freeman, R. B. and Katz, L. F. (1996) Searching for the Effect of Immigration on the Labor Market, The American Economic Review, 86 (2) 246-251.

Borjas, G. J., Freeman, R. B. and Katz, L. F. (1997) How Much Do Immigration and Trade Affect Labor Market Outcomes?, Brookings Papers on Economic Activity, 1:1997 1-90.

Card, D. (1990) The Impact of the Mariel Boatlift on the Miami Labor Market, Industrial and Labor Relations Review, 43 (2) 245-257.

Card, D. (2001) Immigrant Inflows, Native Outflows, and the Local Market Impacts of Higher Immigration, Journal of Labor Economics, 19 (1) 2264.

Card, D. and DiNardo, J. E. (2000) Do Immigrant Inflows Lead to Native Outflows?, NBER Working Paper No. 7578.

Card, D. and Krueger, A. B. (1995) Time-Series Minimum-Wage Studies: A Meta-Analysis, The American Economic Review, 85 (2) 238-243.

Castles, S. and Miller, M. J. (1993) The Age of Migration. London: Macmillan.

Cooper, H. and Hedges, L. V. (1994) (Eds.) The Handbook of Research Synthesis. New York: Russel Sage Fundation

De New, J. P. and Zimmermann, K. F. (1994) Native Wage Impacts of Foreign Labor: A Random Effects Panel Analysis, Journal of Population Economics, 7 177-192.

Djaije, S. (2001) (Eds.) International Migration: Trends, Policies and Economic Impact. London: Routledge

Doucouliagos, C. (1995) Worker Participation and Productivity in LaborManaged and Participatory Capitalist Firms: A Meta-Analysis, Industrial and Labor Relations Review, 49 (1) 58-77.

Doucouliagos, C. (1997) The Aggregate Demand for Labour in Australia: A Meta-Analysis, Australian Economic Papers, 36 (69) 224-242. 
Enchautegui, M. E. (1995) Effects of Immigrants on the 1980-1990 U.S. Wage Experience, Contemporary Economic Policy, XIII 20-38.

Florax, R. J. G. M. (2002a) Accounting for Dependence among Study Results in Meta-Analysis: Methodology and Applications to the Valuation and Use of Natural Resources, Dept of Spatial Economics, Vrije Universiteit, Research Memorandum 2002/5.

Florax, R. J. G. M. (2002b) Methodological Pitfalls in Meta-Analysis: Publication Bias, in Comparative Environmental Economic Assessment, ed. by R. J. G. M. Florax, P. Nijkamp and K. G. Willis. Cheltenham: Edward Elgar, 177-207.

Friedberg, R. M. (2001) The Impact of Mass Migration on the Israeli Labor Market, The Quarterly Journal of Economics, 116 (4) 1373-1408.

Friedberg, R. M. and Hunt, J. (1995) The Impact of Immigrants on Host Country Wages, Employment and Growth, The Journal of Economic Perspectives, 9 (2) 23-44.

Gleser, L. J. and Olkin, I. (1994) Stochastically Dependent Effect Sizes, in The Handbook of Research Synthesis, ed. by H. Cooper and L. V. Hedges. New York: Russel Sage Foundation, 339-355.

Gorter, C., Nijkamp, P. and Poot, J. (1999) (Eds.) Crossing Borders: Regional and Urban Perspectives on International Migration. Aldershot: Ashgate

Greene, W. H. (2003) Econometric Analysis.: Pearson Education.

Greenwood, M. J., Hunt, G. L. and Kohli, U. (1997) The Factor-Market Consequences of Unskilled Immigration to the United States, Labour Economics, 4 (1) 1-28.

Grossman, J. B. (1982) The Substitutability of Natives and Immigrants in Production, The Review of Economics and Statistics, 64 (4) 596-603.

Hartog, J. and Zorlu, A. (2002) The Effect of Immigration on Wages in Three European Countries, IZA Discussion Paper No. 642.

Hofer, H. and Huber, P. (2003) Wage and Mobility Effects of Trade and Migration on the Austrian Labour Market, Empirica, 30 107-125.

Hunt, J. (1992) The Impact of the 1962 Repatriates from Algeria on the French Labor Market, Industrial and Labor Relations Review, 45 (3) 556-572.

IOM (2000) World Migration Report, International Organization for Migration.

Jarrel, S. B. and Stanley, T. D. (1990) A Meta-Analysis of the Union-Nonunion Wage Gap, Industrial and Labor Relations Review, 44 (1) 54-67.

Neumark, D. and Wascher, W. (1998) Is the Time-Series Evidence on Minimum Wage Effects Contaminated by Publication Bias?, Economic Inquiry, 36 (3) 458-470.

Nijkamp, P. and Poot, J. (Forthcoming) The Last Word on the Wage Curve?, Journal of Economic Surveys.

Pedace, R. (1998) The Impact of Immigration on the Labor Market for NativeBorn Workers: Incorporating the Dynamics of Internal Migration, Eastern Economic Journal, 24 (4) 449-462.

Poot, J., Nana, G. and Philpott, B. (1988) International Migration and the New Zealand Economy, Institute of Policy Studies. 
Shadish, W. R. and Haddock, C. K. (1994) Combining Estimates of Effect Size, in The Handbook of Research Synthesis, ed. by H. Cooper and L. V. Hedges. New York: Russel Sage Foundation, 261-281.

Stalker, P. (1994) The Work of Strangers: A Survey of International Labour Migration. Geneva: International Labour Office.

Stanley, T. D. (2001) Wheat from Chaff: Meta-Analysis as Quantitative Literature Review, Journal of Economic Perspectives, 15 (3) 131-150.

Stanley, T. D., Florax, R. J. G. M. and de Groot, H. L. F. (2004) It's All About Power: Differentiating Genuine Empirical Significance from the Artifact of Publication Bias, Mimeo.

Stanley, T. D. and Jarrel, S. B. (1998) Gender Wage Discrimination Bias? A Meta-Regression Analysis, Journal of Human Resources, 33 (4) 947-973.

Sutton, A. J., Abrams, K. R., Jones, D. R., Sheldon, T. A. and Song, F. (2000) Methods for Meta-Analysis in Medical Research. New York: John Wiley and Sons.

The Economist (2002) The Longest Journey: A Survey of Migration. Supplement To, The Economist November 2.

Thompson, S. G. (2001) Why and How Sources of Heterogeneity Should Be Investigated, in Systematic Reviews in Health Care, ed. by M. Egger, G. D. Smith and D. G. Altman: BMJ, 157-175.

van den Bergh, J. C. J. M., Button, K. J., Nijkamp, P. and Pepping, G. C. (1997) Meta-Analysis in Environmental Economics.: Kluwer Academic Publishers.

Welch, F. (1979) Effects of Cohort Size on Earnings: The Baby Boom Babies' Financial Bust, Journal of Political Economy, 87 (5-2) S65-S97.

Winter-Ebmer, R. and Zimmermann, K. F. (1998) East-West Trade and Migration: The Austro-German Case, IZA Discussion Paper No. 2.

Winter-Ebmer, R. and Zweimuller, J. (1996) Immigration and the Earnings of Young Native Workers, Oxford Economic Papers, 48 (3) 473-491.

Woodward, R. T. and Wui, Y.-S. (2001) The Economic Value of Wetland Services: A Meta-Analysis, Ecological Economics, 37 257-270.

Zimmermann, K. F. and Bauer, T. K. (2002) The Economics of Migration. 4 Volumes. Cheltenham, UK and Northampoton, Mass: Edward Elgar. 